to express the hope that the Government will immediately oppose its further progress, and prevent the frustration of the objects of a public Act of Parliament, by enabling a sewer authority or local board to delegate to a private and irrespon. sible body the powers which the Legislature has imposed upon those autborities. We do not see what check there would be upon the expenditure under such an arrangement as this Bill proposes. On the whole, we think it would be most adverse to the interests of the public, and to the progress of sanitary reform, and should, therefore, be thrown out by Parliament.

\section{RETIRING PENSIONS TO DISPENSARY AND POOR-LAW MEDICAL OFFICERS IN IRELAND.}

THE deputation from the Royal College of Surgeons in Ireland and from the Irisb Medical Association-composed of the Vice-President of the College (Prof. Macnamara), the Secretary to the Council (Prof. Hughes), and the Hon. Secretary to the Irish Medical Association (Dr. Quinan)-arrived in town on Wednesday the 10th inst., and waited by appointment upon the Chief Secretary for Ireland, the Earl of Mayo, on the following Friday, with the object of impressing upon his Lordship's attention the claims of Irish medical officers employed under the Poor Laws and Medical Charities Acts to superannuation allowance when unable, from any cause, longer efficiently to discharge their duties. The deputation was accompanied by Prof. Mapother, Mr. Pim, M.P., and Dr. Brady, M.P.; and each argument in their favour was brought under his Lordship's attention, who received the deputation courteously, and listened attentively to their observations, the substance of which has been since embodied in the subjoined letter, which has been addressed to the Irish members individually. His Lordship did not appear to entertain any strong hope that the measure would become law this session; in fact, he seemed to be rather reluctant to increase the present poorrates-a feeling in which he fortified himself by stating that Irish boards of guardians entertained opinions upon the subject somewhat akin to his own. As to the increase in the rates, this would, as we are informed, be of so very trifling a charaeter (not one-fiftieth of a penny) that it should not be allowed to enter into consideration where a question of such justice to a meritorious professional class is concerned; and as to the disinclination of boards of guardians to being invested with such permissive powers, we suspect that his Lordship is misinformed. This is a point, however, which could easily be cleared up; and were we to venture to offer advice to our Irish friends, it would be, in case of the not improbable falling through of this Bill, that they should employ the period between this and the next meeting of Parliament in exciting the sympathies of the Irish boards of guardians in support of this most just claim of their medical officers.

As Members of a Deputation from the Royal College of Surgeons in Ireland, we beg to submit the following reasons in favour of the granting of retiring pensions to dispensary and Poorlaw medical officers in Ireland, after twenty years' service, and after having attained their sixtieth year of age, who may be rendered incapable by disease or accident from performing their professional duties.

No. 1. Poor-law medical officers are obliged to place their whole time, both night and day (not excepting Sunday), at the disposal of those who appoint them.

No. 2. The point so forcibly brought before Lord Mayo by Dr. Brady, -namely, that the fact of the dispensary and poorhouse medical officers being permitted to practise enables them to accept the Poor law appointments for at least one-fourth of the salary they should otherwise obtain-by which the rates are lessened, and by the saving of which, whilst in youth and health, the medical officer is fairly entitled to a retiring pension when, by old age, disease, or accident, he becomes disabled from efficiently carrying out his professional duties.

No. 3. By a recent order of the Poor-law Commissioners, a Poor-law medical offecr is probibited from accepting any appointment-a coronership, for instance, - which may possibly call him beyond the outline of his district.

No. 4. It is obvious that when a medical officer is disabled from any of the causes already alluded to, unless he resign his office, which he seldom can afford to do, those poor patients who are confided to his professional care must suffer; but if there were a retiring salary secured to those unequal to discharge their professional duties efficiently, the officers so circumstanced would voluntarily resign their offices, and thas make way for younger and more active medical men.

No. 5. It stands to reason that the prospect of an equitable retiring allowance in an infirm old age would assist in procuring for the sick poor, and the community in the several Poorlaw districts, medical practitioners of the highest qualifications and abilities.

No. 6. Lastly, it cannot be too forcibly impressed on the ratepayers, that as it is proposed in Sir Coleman O'Loghlen's Bill, at present before Parliament, that the dispensary and Poor-house medical officers can only (when disabled by old age or infirmity) be entitled to two-thirds of their salarjes, and that one-third is to be paid out of the Consolidated Fund, that consequently the ratepayers will be called on to pay only onethird of the retired medical officers' former salaries.

It may be right here to add that, on inquiry, we have reasons to believe that the number of old and infirm medical poor house officers at present in Ireland, likely to seek relie by a retiring salary, does not exceed twenty.

The granting of retiring salaries to Poor-law medical officers, as contemplated by Sir Coleman O'Loghlen's Bill, is only permissive, not obligatory.

Rawdon Macnamara, M.D., F.R.C.S.I., Vice-president of the Royal College of Surgeons,

lreland.

Stannus Hughes, M.D. F.R. C.S.I., Secretary of Council, and Professer of Surgery in the Royal C,llege of Surgeons, Ireland

E. I. Quinan, M.D., F.R.C.S.I. Hon. Sec. Irish Medical Association.

The Westminster Palace Hotel June 15th, 1868 .

P.S.-It is self-evident that no one would avail himself of the boon unless fairly worn out, - -as, so long as he was able to work, he would not like to introduce a rival into tine centre of his practice.

\section{THE ROYAL COLLEGE OF SURGEONS.}

\section{ABSTRACT OF MR. LE GROS CLARK'S IECTURES ON SURGICAL DIAGNOSIS.}

\section{LECTURE III}

Ix the first part of his third lecture $\mathrm{Mr}$. Clark continued the consideration of the general principles of surgical diagnosis, which have formed the subject of the two preceding lectures. He commenced by glancing at the subjects of pain and sleep. The former was regarded by pbysiologists as a less unmixed evil than it was popularly believed to be. It afforded considerable aid to diagnosis, especially in its numerous varieties, which were so of ten alled to special diseases. Sympathetic pain, too, was often useful. He believed the shock of pain had been over-estimated, for severe and long-continued pain, though exhausting, was very rarely fatal, per se. Sleep was. often a useful aid to diagnosis-its disturbance the first note of warning, its return the harbinger of improvement. A hsence of sleep was more siguificant than disturbed conditions. Much might often be learned by watching the action of anodynes. In the sleeplessness of nervous excitement their effect was deep and prolonged, while in febrile states the sleep was disturbed. by dreams and startled wakings; then, indeed, opium often could not be borne.

Having completed the enumeration of the subjective symptoms, the lecturer alluded to the varions objective sions useful in diagnosis. Deformity was very important, and in estimating this by comparison of the two sides of the body it was well to employ one sense only at a time. The indications to be derived from colour, transparency, local changes of temperature, consistence, edema, crepitation, crepitus, and fuctuation were then spoken of; and after alluding to the diagnostic value of treatment, a test which should never be employed to the possible injury of the patient, Mr. Clark passed on to consider the main subject of his lectures--the application of these principles to shock and visceral lesions.

The great characteristic of shock was the vital depression produced by some exciting cause, acting primarily on the 